\title{
Extent of gill pathology in the toadfish Tetractenos hamiltoni caused by Naobranchia variabilis (Copepoda: Naobranchiidae)
}

\author{
Frank R. Roubal* \\ Department of Parasitology, The University of Queensland, Brisbane 4072, Queensland, Australia
}

\begin{abstract}
Sanguinivorous Naobranchia variabilis prefer the first gill arch, external hemibranch and anterior end of the gill arch. The smallest $N$ variabilis observed attached to fish by a thin filament which connects fused tips of second maxillae to a 'plug' inserted into the gill tissue. Second maxillae enlarge to encircle and increasingly compress the gill filament, which results in a thin layer of epithelium and connective tissue overlying the cartilaginous supporting bar. Early juveniles cause little tissue proliferation, but the extent of proliferated epithelial and connective tissue (PR) adjacent to the maxillae increases from late juveniles to subadult and adult copepods. Most variation in length of gill filament damage (PL, proliferated and compressed tissue) among age classes is explained by maxilla length ( $\mathrm{ML}$, length of compressed gill filament); adult trunk width (TRW) explains an extra, small amount of variation, but not trunk length (TRL) or total fish length (TL). Most variation in ML is explained by TRW of adults, subadults and late juveniles, and TRL of early juveniles. PR is explained by TRW for adults, but by ML for other ages. These patterns are due to elongation of the juvenile trunk during growth and lateral expansion of adult egg pouches during maturation. Up to $38 \mathrm{~N}$. variabilis, average (avg.) $=9.3$, infected individual Tetractenos hamiltoni and damaged up to $3.4 \%$ (avg. $0.72 \%$ ) of total filament length and $8.6 \%$ (avg. $2.1 \%$ ) of gill filaments per fish.
\end{abstract}

KEY WORDS: Naobranchia variabilis - Copepoda - Parasite - Ecology · Pathology · Toadfish · Tetractenos hamiltoni

\section{INTRODUCTION}

Naobranchia variabilis infects a wide range of marine fish in the Atlantic and in India, as well as the banded toadfish Sphaeroides pleurosticus in Moreton Bay, Australia (Kabata 1968). The parasite also occurs on the common toadfish Tetractenos hamiltoni in Moreton Bay. The parasite attaches by using highly modified second maxillae that encircle the gill filament, but little is known about its biology, including the life cycle of this widespread parasite, and in particular about the damage that it causes to fish gills. There are few quantitative data for the extent of pathology caused by ectoparasites in wild fish populations. Measurements of the damage caused by parasitic copepods to the gill

\footnotetext{
•E-mail: taylorja@usq.edu.au
}

surface area of fish have been made in a few studies, e.g. Löpmann (1940), Kabata \& Cousens (1977), Sutherland \& Wittrock (1985), Roubal (1987a, b).

The present study was done to investigate the pathology caused by Naobranchia variabilis on the gills of Tetractenos hamiltoni. The spatial distribution of the parasite was mapped, and the extent of gill damage was quantified and assessed against parasite size, fish size and intensity of infection.

\section{MATERIALS AND METHODS}

Tetractenos hamiltoni were collected by beam trawl from shallow water in western Moreton Bay, Queensland, Australia, and placed in plastic bags on ice for up to $2 \mathrm{~h}$, then preserved in $4 \%$ formaldehyde. Fish were washed in fresh water, the total length $(\mathrm{TL}, \mathrm{cm})$ 
measured and the gills excised. The number, size and distribution of Naobranchia variabilis on the gills were recorded. The length (TRL) and width (TRW) of the trunk, and length of the second maxilla ( $M L$; measured parallel to the long axis of the primary gill filament) were measured. The copepods were identified as either early juveniles (trunk absent or much smaller than neck; second maxilla small), late juveniles (trunk formed but small, with no evidence of egg pouches), subadults (egg pouches evident with internal supports but no eggs) or adults (eggs present in at least 1 pouch or pouches swollen but eggs shed, or trunk large but no eggs present). Representative copepods from each age class were cleared in $80 \%$ lactic acid and drawn with the aid of a calibrated camera lucida. Some parasites were detached with a sharp probe from the primary gill filament and the underlying damage examined. Gill filaments with attached parasites from freshly preserved material were embedded in wax, sectioned and stained with haematoxylin and eosin (H\&E). To determine if gut pigment in $N$. variabilis was derived from a blood diet, the rate of bleaching of the pigment in hydrogen peroxide was examined (Llewellyn 1954). $N$. variabilis were cut in half and placed in $30 \mathrm{mg} \mathrm{ml}^{-1}$ (10 volume) hydrogen peroxide for up to $12 \mathrm{~h}$. Control tissues also placed in hydrogen peroxide at the same time were the gut contents of the sanguinivorous copepod Lernanthropus atrox, and pieces of fin and kidney with melanin deposits. All of these tissues had been fixed in formalin and stored in $70 \%$ ethanol, then washed several times in fresh water.

The number of gill filaments from 17 fish (TL 4.3 to $10.8 \mathrm{~cm}$ ) were counted. The length of every fifth filament from the external and internal hemibranchs of each of the 3 gill arches on 1 side of the head was measured with a calibrated microscope. The average gill filament length was calculated and multiplied by the total number of filaments to estimate total gill filament length (modified from Roubal 1987a). Least squares regression analyses were done to derive the relationship of best fit between total filament length (TFL, mm) and fish size ( $\mathrm{TL}, \mathrm{cm})$. Stepwise regression was done to investigate the relationships between length of damaged gill filament (PL), proliferated tissue (PR), ML, TRL and TRW of individual parasites within each age class, as well as TL. The extent of damage caused by the assemblage of $\mathrm{NaO}$ branchia variabilis on a fish was the sum of damage caused by individual parasites. In some cases parasites and their attachment were damaged or dislodged during dissection, so ML and PL were estimated from the derived regression equations. These estimates were used only to calculate total extent of gill damage.

\section{RESULTS}

\section{Spatial distribution}

Individuals of Naobranchia variabilis were situated on the external surface of hemibranchs and orientated with the mouth parts and trunk pointed towards the gill arch (Fig. 1). Most adult, subadult, late juvenile and early juvenile $N$. variabilis attached to the first gill arch and the fewest to the third gill arch (Table 1). Most attached near the base of the gill filament, in the anterior zone and on the external hemibranch; few $N$. variabilis attached to the middle zone of any gill arch. Ten fish with only $1 N$. variabilis were examined; these parasites preferred either the first or second gill arch, and the anterior zone (Table 1).

\section{Pathology}

A recently settled parasite attached itself by means of a thin filament arising from the fused distal tips of the second maxillae (Fig. 2) and inserted into the gill tissue. The end of the filament in the gill tissue was swollen into a bell-shaped plug (Fig. 2). This small larva $(<0.5 \mathrm{~mm})$ eroded the gill tissue in its vicinity. Further metamorphosis of Naobranchia variabilis was associated with an increase in size. The second maxillae enlarged into strap-like structures, with a central band of muscle, that encircled the primary gill filament in opposite directions to join beneath the parasite so that the separate straps lay side-by-side (Fig. 3). The juvenile maxillae caused a small depression in the gill

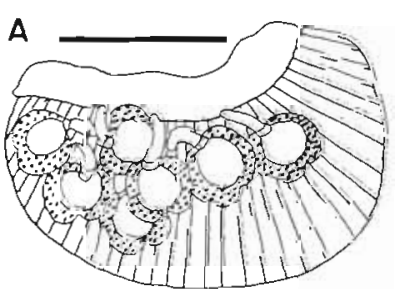

B

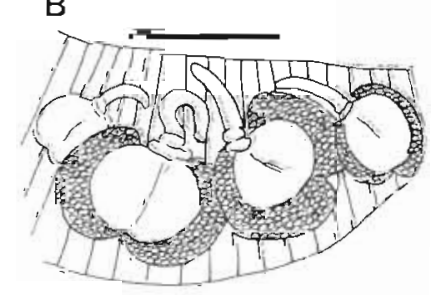

Fig. 1. Gills of Tetractenos hamiltoni infected with Naobranchia variabilis. (A) Heavy infection on external hemibranch of first gill arch. (B) Relative sizes of 2 large adults, 1 small adult and subadult. Scale bar $(A)=6 \mathrm{~mm},(B)=3 \mathrm{~mm}$ 
Table 1. Spatial distribution of 4 age classes of Naobranchia variabilis on the gills of Tetractenos hamiltoni. The distribution of $N$. variabilis in 10 fish with 1 parasite only is shown in parentheses

\begin{tabular}{|c|c|c|c|c|c|}
\hline & Adult & Subadult & $\begin{array}{c}\text { Late } \\
\text { juvenile }\end{array}$ & $\begin{array}{c}\text { Early } \\
\text { juvenile }\end{array}$ & Sum \\
\hline \multicolumn{6}{|l|}{ Gill } \\
\hline 1 & $202(1)$ & $68(2)$ & $25(1)$ & $26(2)$ & $321(6)$ \\
\hline 2 & $99(1)$ & $27(2)$ & $24(0)$ & $13(1)$ & $163(4)$ \\
\hline 3 & 42 & 13 & 15 & 7 & $77(0)$ \\
\hline \multicolumn{6}{|c|}{ Hemibranch } \\
\hline External & $215(2)$ & $66(4)$ & $38(1)$ & $24(1)$ & $343(8)$ \\
\hline Inteirnal & $128(0)$ & $42(0)$ & $26(0)$ & $22(2)$ & $218(2)$ \\
\hline \multicolumn{6}{|l|}{ Zone } \\
\hline Anterior & $316(2)$ & 99 (4) & $61(1)$ & $41(3)$ & $517(10)$ \\
\hline Middle & 6 & 4 & 0 & 0 & $10(0)$ \\
\hline Posterior & 21 & 5 & 3 & 5 & $34(0)$ \\
\hline
\end{tabular}

filament (Fig. 3). Further growth of the parasite was associated with enlargement of the neck, trunk and maxillae (Table 2). The maxillae increased in length, width and thickness, which increased the length of gill filament affected and increasingly compressed the underlying gill tissue (Figs. 4 \& 5). The encircling maxillae were wider at the margin of the gill filament away from the parasite (Figs. $3 \& 4$ ). Bands of muscle within the maxillae (13 to 18 in each adult maxilla) were oriented in the same direction around the gill filament as the maxillae, with the thickest bands at the centre of each strap. The cuticle between the muscle bands became thicker, and was thickest along the middle of each strap and on the margin between the adjacent straps.
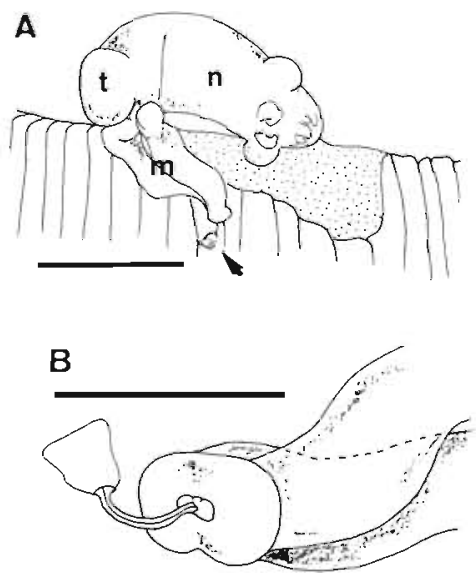

Fig. 2. Early stage of Naobranchia variabilis attached to gill filament. (A) Filament (arrow) inserted in gill tissue extends from second maxillae (m). Small trunk (t) and neck (n) with mouth parts also indicated. Stippled area: eroded gill tissue. (B) Enlarged view of distal end of fused second maxillae with filament. Scale bar $(A)=0.25 \mathrm{~mm},(B)=0.1 \mathrm{~mm}$

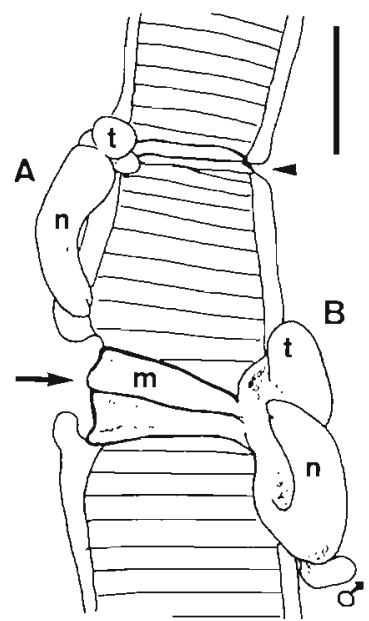

Fig. 3. Juveniles of Naobranchia variabilis attached to gill filament. (A) Early juvenile with thin maxillae encircling filament (arrowhead), with little proliferated tissue; neck (n) distinct but trunk (t) small. (B) Late juvenile with attached male, more tissue damage (arrow), and larger encircling maxillae (m), neck and trunk. Scale bar $=0.5 \mathrm{~mm}$

There was little gill tissue proliferation beside the encircling maxillae of early juveniles; the amount of proliferation increased as the parasite matured. There was complete loss of respiratory lamellae beneath the maxillae (Figs. $4 \& 5$ ). The diameter of the gill filament encircled by the maxillae was much reduced, and a

Table 2. Size $(\mu \mathrm{m})$ of Naobranchia variabilis. Trunk length (TRL), trunk width (TRW), maxilla length (ML) and length of gill filament damaged (PL) are shown for adults, subadults and late and early juveniles. Proliferated tissue $(P R)=P L-$ $\mathrm{ML}$. Values given are sample size (N), mean, minimum (Min), maximum (Max) and standard deviation (SD)

\begin{tabular}{|lllrrrr|}
\hline \multirow{2}{*}{ Age class } & \multirow{2}{*}{$N$} & Variable & Mean & Min & Max & SD \\
\hline Adult & \multirow{2}{*}{423} & TRL & 1576.0 & 840 & 2590 & 293.2 \\
& & TRW & 2102.2 & 910 & 3080 & 419.9 \\
& & ML & 869.6 & 420 & 1260 & 156.5 \\
& & PL & 1689.1 & 420 & 2800 & 349.0 \\
Subadult & & PR & 823.6 & 0 & 1750 & 262.0 \\
& \multirow{2}{*}{145} & TRL & 1098.3 & 560 & 1750 & 232.1 \\
& & TRW & 1266.3 & 490 & 2100 & 337.3 \\
& & ML & 671.1 & 350 & 1120 & 138.4 \\
Late juvenile & & PL & 1241.7 & 560 & 2380 & 321.8 \\
& & PR & 579.0 & 70 & 1330 & 241.1 \\
& & TRL & 689.8 & 420 & 1050 & 162.7 \\
& & TRW & 689.8 & 350 & 1260 & 192.1 \\
Early juvenile & ML & 443.3 & 210 & 700 & 122.0 \\
& & PL & 599.7 & 210 & 1190 & 201.1 \\
& & PR & 165.7 & 0 & 490 & 130.6 \\
& & TRL & 263.2 & 7 & 490 & 97.7 \\
& & TRW & 229.1 & 7 & 490 & 92.4 \\
& & ML & 156.1 & 35 & 350 & 88.7 \\
& & PL & 177.8 & 335 & 560 & 119.1 \\
& & PR & 16.8 & 0 & 280 & 58.1 \\
& & & & & & \\
& & & & & \\
& & & & &
\end{tabular}




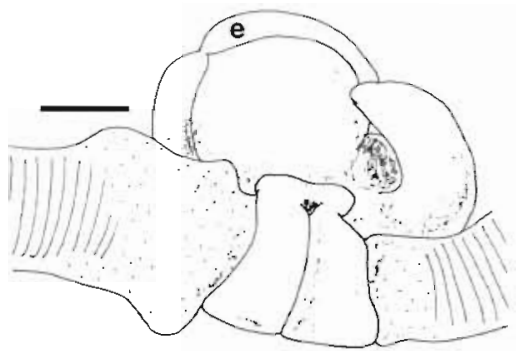

Fig. 4. Subadult Naobranchia variabilis. Egg pouches (e) evident. Proliferated tissue stippled. Scale bar $=0.5 \mathrm{~mm}$

thin epithelium covered the cartilaginous bar and constricted afferent and efferent blood vessels within the primary gill filament. In some cases where the head of the parasite was close to the gill arch there was a localised proliferation of epithelium on the side of the gill arch adjacent to the parasite.

Histological sections revealed that the majority of proliferated tissue adjacent to the compressed region consisted of hyperplastic epithelial Malpighian cells with the basal layer distinctly columnar. There was proliferated connective tissue within the dermis, but few infiltrating cells. The afferent and efferent blood vessels within the proliferated region adjacent to the compressed regions, particularly with young parasites, were engorged with red blood cells (Fig. 6A). Compressed epithelial cells surrounded the compressed gill filament. There was little connective tissue, and the blood vessels were difficult to locate. The epithelial and dermal tissues were compressed onto the cartilaginous supporting bar within the gill filament (Fig. 6B). The cartilage was little affected, but had rounded sur-

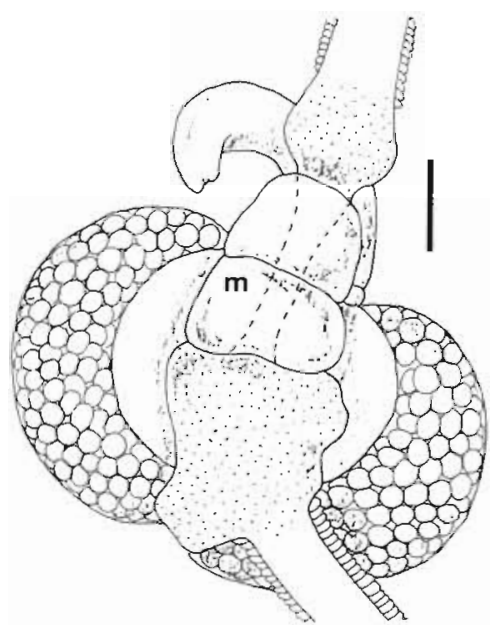

Fig. 5. Adult Naobranchia variabilis. Egg pouches with eggs extend trunk laterally. Proliferated tissue stippled compressed gill filament encircled by second maxillae (m). Scale bar $=0.5 \mathrm{~mm}$
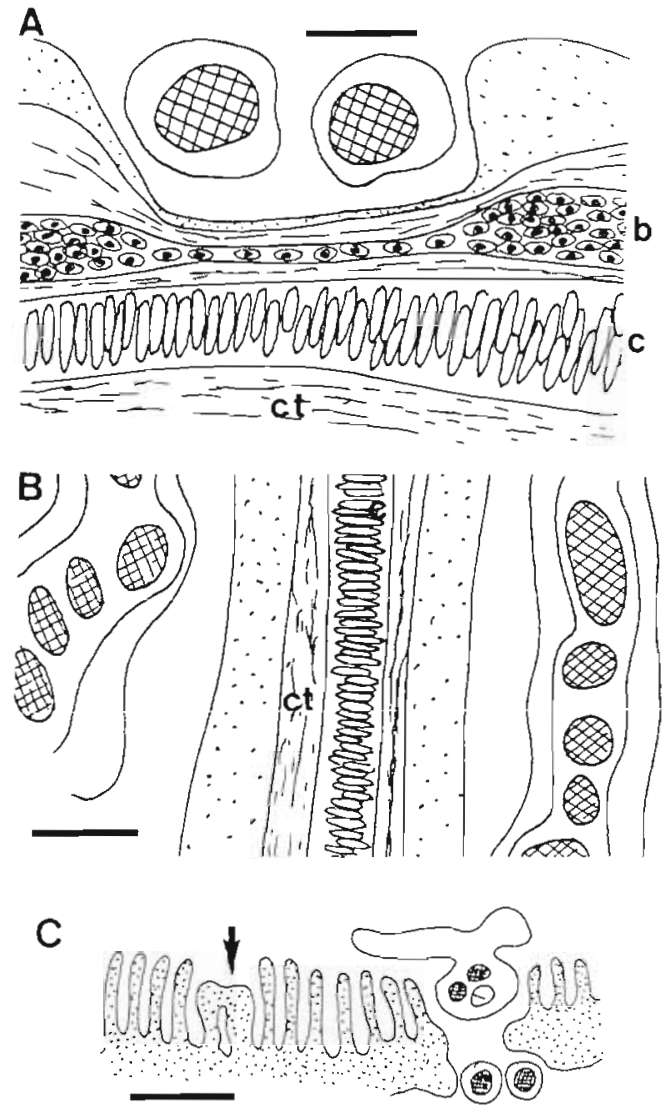

Fig. 6. Histological sections of attached Naobranchia variabilis. (A) Juvenile second maxillae with muscle bands (crosshatched) encircle filament and compress epithelium (stippled). Blood vessel (b) compressed beneath maxillae but engorged on either side. Cartilage (c) and adjacent connective tissue (ct). (B) Second maxillae of adult with several muscle bands (cross-hatched) encircle filament and compress epithelium (stippled) onto thin layer of connective tissue (ct) and cartilage (c). No blood vessels evident in this or adjacent sections. Space between parasite and tissue is artifact. (C) Attached early juvenile with rounded second maxillae and feeding site (arrow). Scale bar (A \& B) $=0.05 \mathrm{~mm},(\mathrm{C})=$ $0.2 \mathrm{~mm}$

face projections associated with the areas of thickened cuticle in the maxillae.

In histological sections, the gill filament in the vicinity of the mouth parts of the early juvenile was eroded and had proliferated epithelium; this feeding site was separate from where the parasite attached (Fig. 6C). A dark pigment observed in the gut of the parasite was evident in all age classes. The pigment was bleached by hydrogen peroxide at a rate similar to blood residue in the gut of the sanguinivorous Lernanthropus atrox, but the melanin control in the fin and kidney bleached only a little in the same period. The gut pigment is most likely a residue from a blood diet. 


\section{Extent of pathology}

The extent of damage to the gills caused by individual parasites (PL) was restricted largely to the gill filament where the parasite attached, and consisted of compressed gill filament beneath the second maxilla $(=\mathrm{ML})$ as well as proliferated gill tissue $(\mathrm{PR}=\mathrm{PL}-\mathrm{ML})$ on either side of the maxilla. The sizes of parasites in different age classes, as well as ML, PL and PR, are shown in Table 2. There was a distinct increase in mean values of all variables as the parasite matured, but the range of values overlapped between adjacent age classes. In one case there was no apparent proliferation caused by an adult; this parasite was small ( TRL $=420 \mu \mathrm{m}$, TRW $=420 \mu \mathrm{m}$ ) with a few eggs.

Stepwise regression of PL on ML, TRW, TRL and TL over all age classes showed that ML explained most variation whereas TRW was significant only for adults; TRL and TL were insignificant factors in all age classes (Table 3). ML explained least PL variation in the adult age class and most in early juveniles.

Stepwise regression was done to determine which of TRL, TRW and TL accounted for significant variation in ML. Over all age classes, TRW was a more important variable than TRL, and TL had a significant, negative effect although it explained little of the total variation (Table 3). Among age classes, TRW explained most variation but was not a significant fac- tor for early juveniles, wherein TRL was the only significant variable. TRL explained a significant, but small amount of variation for adults and subadults. In addition, TL had a small, significant, but negative effect on subadult ML.

There were no significant correlations $(p>0.5)$ between ML and TL for subadult, late and early juveniles, but TL and adult ML were correlated positively $\{r=0.29, p<0.001)$. Partial correlations between ML and TL adjusted for either TRW or TRL were not significant for early and late juveniles, but TL and subadult ML were correlated negatively when adjusted for either TRW $(r=-0.21, p=0.14)$ or TRL $(r=-0.19$, $\mathrm{p}=0.02$ )

Stepwise regression of PR on ML, TRW, TRL and TL showed that over all age classes TRW explained most variation with a small amount explained by ML (Table 3). This result was similar in the adult age class, but ML explained most variation in PR for subadults, and no relationships were found for juvenile parasites. When PR was regressed on $\mathrm{ML}$, significant relationships were found for adult and subadult age classes only (Table 3). However, subadults had a greater slope than adults. Thus, compression caused more damage than proliferation (Table 2), but relative to length of maxilla subadults caused more proliferation than adults. Adult Naobranchia variabilis caused the most damage (Table 2).

Table 3. Naobranchia variabilis size and extent of pathology. Relationships between maxilla length (ML, $\mu \mathrm{m}$ ), trunk width (TRW, $\mu \mathrm{m})$, trunk length (TRL, $\mu \mathrm{m})$, fish length $(\mathrm{TL}, \mathrm{cm})$, damage to gill filament (PL, $\mu \mathrm{m})$ due to proliferated tissue (PR, $\mu \mathrm{m})$ and tissue compressed beneath maxilla ( $=M L$ ). Equations were derived by stepwise regression; significance level and percent of variation explained by each variable are shown. Age, parasite age class (Ad: adult, Sa: subadult, LJ: late juvenile, EJ: early juvenile); DV: dependent variable. na: not applicable; nf: not fitted; Sig.: significance level (ns $p \geq 0.05, \cdot p<0.05, \cdots p<0.01, \cdots p<0.001$ )

\begin{tabular}{|c|c|c|c|c|c|c|c|c|c|c|c|}
\hline \multirow[t]{3}{*}{ Age } & \multirow[t]{3}{*}{ DV } & \multirow[t]{3}{*}{ Equation } & \multicolumn{9}{|c|}{ Independent variables } \\
\hline & & & \multirow{2}{*}{$\begin{array}{l}\text { Intercept } \\
\text { Sig. }\end{array}$} & \multirow{2}{*}{$\begin{array}{l}\text { ML } \\
\text { Sig. }\end{array}$} & \multicolumn{3}{|c|}{ TRW } & \multicolumn{2}{|l|}{ TRL } & \multicolumn{2}{|l|}{$\mathrm{TL}$} \\
\hline & & & & & $\%$ & Sig. & $\%$ & Sig. & $\%$ & Sig. & $\%$ \\
\hline All & PL & $-72.96+1.36 \mathrm{ML}+0.2 \mathrm{TRW}+0.105 \mathrm{TRL}$ & ns & $\cdots$ & 79 & $\cdots$ & 3 & • & 0.12 & ns & \\
\hline Ad & PL & $51.13+1.22 \mathrm{ML}+0.28 \mathrm{TRW}$ & ns & $\cdots$ & 52 & $\cdots$ & 7 & ns & & ns & \\
\hline $\mathrm{SA}$ & PL & $76.05+1.76 \mathrm{ML}$ & ns & $\cdots$ & 54 & ns & & ns & & ns & \\
\hline LJ & PL. & $19.95+1.34 \mathrm{ML}$ & ns & $\cdots$ & 62 & ns & & ns & & ns & \\
\hline EJ & PL & $-26.13+1.27 \mathrm{ML}$ & ns & $\cdots$ & 80 & ns & & ns & & ns & \\
\hline All & ML & $323.9+0.18 \mathrm{TRW}+0.20 \mathrm{TRL}-15.2 \mathrm{TL}$ & $\cdots$ & na & & $\cdots$ & 73 & $\cdots$ & 1.9 & $\because$ & 0.4 \\
\hline Ad & ML & $346.2+0.17 \mathrm{TRW}+0.11 \mathrm{TRL}$ & $\cdots$ & na & & $\cdots$ & 37 & $\cdots$ & 1.7 & ns & \\
\hline SA & ML & $402.8+0.18 \mathrm{TRW}+0.20 \mathrm{TRL}-18.6 \mathrm{TL}$ & $\cdots$ & na & & $\cdots$ & 48 & $\cdots$ & 2.6 & $\cdots$ & 2.3 \\
\hline LJ & ML & $181.6+0.38$ TRW & $\cdots$ & na & & $\cdots$ & 35 & ns & & ns & \\
\hline EJ & ML & $6.25+0.6 \mathrm{TRL}$ & ns & na & & ns & & $\cdots$ & 39 & ns & \\
\hline All & $\mathrm{PR}$ & $-73.0+0.2 \mathrm{TRW}+0.36 \mathrm{ML}$ & $\cdot$ & $\cdots$ & 2 & $\cdots$ & 55 & ns & & ns & \\
\hline Ad & PR & $51.13+0.28 \mathrm{TRW}+0.22 \mathrm{ML}$ & ns & $\cdots$ & 1 & $\cdots$ & 26 & ns & & ns & \\
\hline SA & PR & $76.05+0.76 \mathrm{ML}$ & ns & $\cdots$ & 18 & ns & & ns & & ns & \\
\hline LJ, EJ & PR & No equation & ns & ns & & ns & & ns & & ns & \\
\hline $\mathrm{Al}$ & PR & $-84.2+1.02 \mathrm{ML}$ & ns & $\cdots$ & 49 & $\mathrm{nf}$ & & $\mathrm{nf}$ & & nf & \\
\hline $\mathrm{Ad}$ & PR & $248.2+0.66 \mathrm{ML}$ & - & $\cdots$ & 15 & nf & & nf & & nf. & \\
\hline SA & $\mathrm{PR}$ & $76.05+0.76 \mathrm{ML}$ & ns & $\cdots$ & 18 & $\mathrm{nf}$ & & $\mathrm{nf}$ & & $\mathrm{nf}$ & \\
\hline $\mathrm{LJ}, \mathrm{EJ}$ & $\mathrm{PR}$ & No equation & ns & ns & & $\mathrm{nf}$ & & nf & & $\mathrm{nf}$ & \\
\hline
\end{tabular}




\section{Morphometrics of toadfish gills}

Toadfish in the TL range 4.3 to $10.8 \mathrm{~cm}(\mathrm{n}=17)$ had between 330 and 460 gill filaments, and the nonlinear relationship between number of filaments and TL was described by the cubic equation: number of filaments $=-862.05+2.296 \mathrm{TL}^{3}-57.1 \mathrm{TL}^{2}+471.1 \mathrm{TL}\left(\mathrm{r}^{2}=0.93\right)$. The corresponding range of TFL in these fish was 443 to $2471 \mathrm{~mm}$. The relationship between TFL (mm) and TL $(\mathrm{cm})$ was described adequately by a linear regression equation: TFL $=-693.09+276.063 \mathrm{TL}\left(\mathrm{r}^{2}=\right.$ $0.96)$. These equations were used to estimate the number of gill filaments and total filament length in order to determine the percentage of these values damaged by all Naobranchia variabilis on individual fish.

\section{Total gill damage per fish}

Infected toadfish had an average of 9.3 (1 to 38 ) parasites per fish (Table 4, Fig. 7 A). Of the 88 infected fish, 71 fish had at least 1 adult (avg. $=7.6$ per fish), 61 fish had at least 1 subadult (avg. $=2.98$ ), 22 fish had at least 1 late juvenile (avg. $=2.4$ ), and 16 toadfish had at least 1 early juvenile parasite (avg. $=2.6$ ). The greatest intensities occurred in the 9 to $10 \mathrm{~cm}$ TL range.

The greatest damage, expressed as total damaged filament length (Fig. 7B), occurred between 9 and $10 \mathrm{~cm}$ TL. Relative to the intensity data in Fig. $7 \mathrm{~A}$, there was a general decline in value of points relative to the maximum value, especially in those fish infected with small parasites. When damage was expressed as a percentage of TFL (Fig. $7 \mathrm{C}$ ), values for fish $<8.5 \mathrm{~cm}$ increased whereas values for fish $>10 \mathrm{~cm}$ decreased relative to Fig. $7 \mathrm{~B}$ because smaller fish have less total gill filament length. Total gill damage did not exceed $3.4 \%$ of TFL, most of which was due to the adult parasites (Table 4). Since it was rare for more than 1 parasite to attach to a primary gill filament, the percentage of gill filaments affected (Fig. 7D) was similar to the intensity of infection (Fig. 7A), and, unlike TFL, there was little difference in number of filaments between large and small fish. Between 0.22 and $8.6 \%$ (avg. $=2.14 \%$ ) of gill filaments were damaged (Table 4).

\section{DISCUSSION}

Like many monogenean and copepod ectoparasites, Naobranchia variabilis shows a definite site preference on its host. This preference is for the ends of the gill arch, particularly the first gill arch. Only in heavy infections are less proferred areas occupied. The lemaneopodid Alella macrotrachelus attaches to the gill tips of Acanthopagrus australis, but unlike $N$. variabilis, individuals of $A$. macrotrachelus tend not to occur in close proximity to each other (Roubal 1989). This may be explained by differences in resource utilisation. The histophagous $A$. macrotrachelus browse on the tips of the gill filaments and tend to exclude conspecifics from their vicinity, whereas the sanguinivorous $N$. variabilis have a usually unlimited food supply, so there is little intraspecific competition for food and the parasites can attach close to each other. Reproductive success is not affected, whether or not the female parasites are in close proximity $(N$. variabilis) or scattered over the gills (A. macrotrachelus), despite the fact that in both groups the male is small and short-lived.

The life cycles of the Naobranchiidae have not been elucidated. Kabata (1981) suggested a close evolutionary relationship between the Naobranchiidae and

Table 4. Extent of gill damage per fish caused by different age classes of Nabranchia variabilis. Intensity shows number of fish infected, mean number of parasites per fish and range for number of parasites per fish ( $N$, mean, range). Damage caused per fish is expressed as total length of gill filaments affected (damage/fish, mm), percentage of total filament length (\%TFL) affected and percentage of total number of gill filaments (\% fils) affected. Percentage of TFL affected by individual parasites (\% TFL ind.) also shown

\begin{tabular}{|lllllll}
\hline \multirow{2}{*}{ Age class } & & Intensity & \multicolumn{3}{c}{ Total gill pathology } & \% fils \\
& & & Damage/fish & TFL ind. \\
Adult & N, mean & $71,7.6$ & 13.0 & 0.68 & 1.76 & 0.09 \\
& Range & $1-27$ & $1.1-54.6$ & $0.07-2.83$ & $0.22-6.29$ & $0.05-0.15$ \\
Subadult & N, mean & $61,2.98$ & 3.76 & 0.21 & 0.69 & 0.07 \\
& range & $1-14$ & $0.82-17.9$ & $0.04-0.9$ & $0.23-3.26$ & $0.03-0.14$ \\
Late juvenile & N, mean & $22,2.4$ & 1.4 & 0.08 & 0.55 & 0.03 \\
& Range & $1-8$ & $0.28-4.22$ & $0.02-0.23$ & $0.22-1.87$ & $0.01-0.07$ \\
Early juvenile & N, mean & 162.6 & 0.44 & 0.02 & 0.57 & 0.009 \\
& Range & $1-6$ & $0.14-1.05$ & $0.01-0.05$ & $0.23-1.38$ & $0.001-0.03$ \\
Pooled & N, mean & $88,9.31$ & 13.6 & 0.72 & 2.14 & 0.08 \\
& Range & $1-38$ & $0.6-65.3$ & $0.03-3.39$ & $0.22-8.61$ & $0.002-0.15$ \\
\hline
\end{tabular}



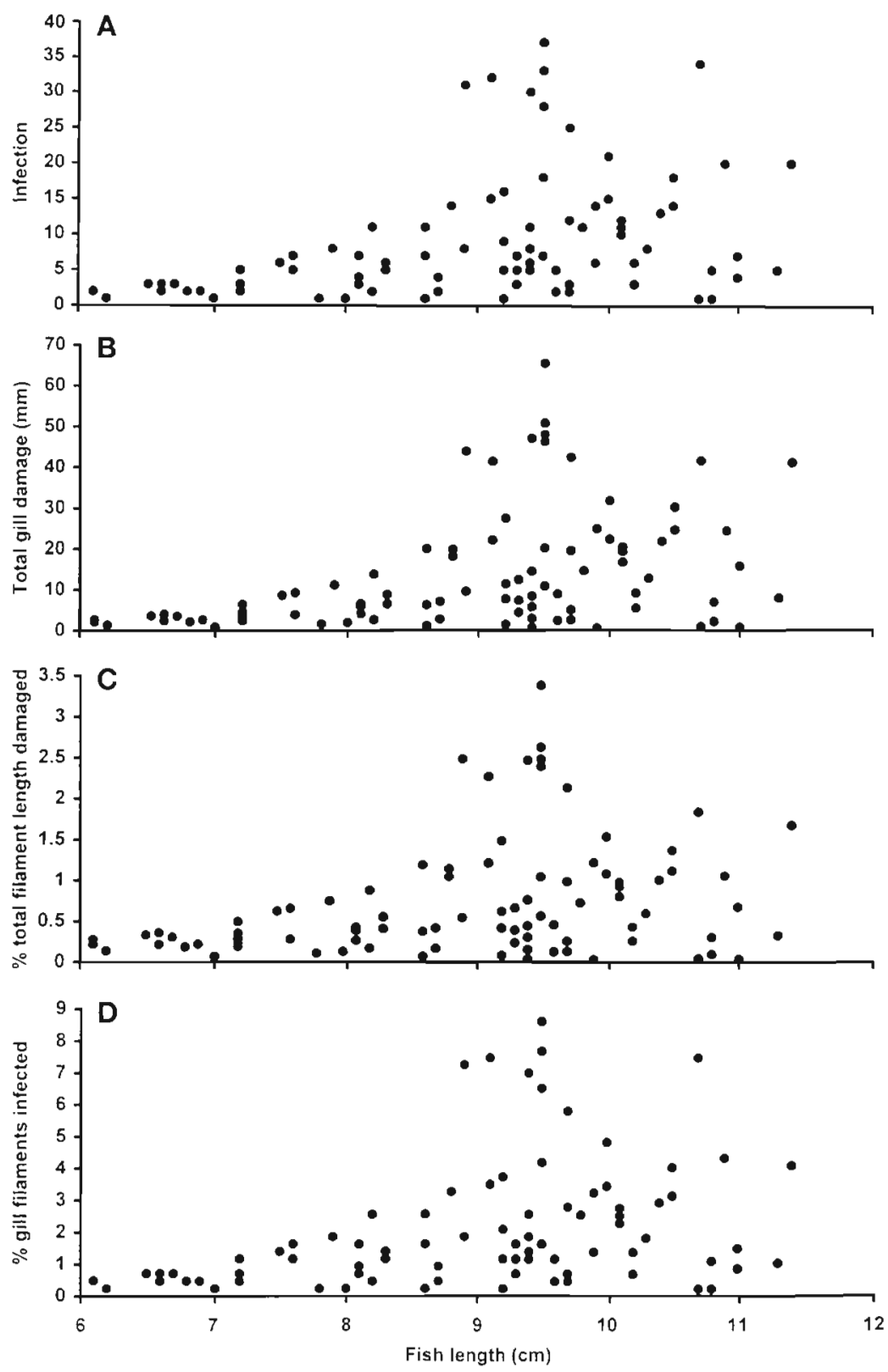

Fig. 7. Damage to gills of Tetractenos hamiltoni of different sizes infected with Naobranchia variabilis. (A) intensity, (B) total gill damage, (C) percentage of total gill filament length damaged, (D) percentage of gill filaments damaged with at most 1 parasite per filament

Clavella- branch of the Lernaeopodidae. The Clavellabranch has an abbreviated life cycle (Heegaard 1947, Shotter 1971), but Piasecki (1989) concluded that there was no need to discern 2 types of life cycle within the Lernaeopodidae and considered the pupa of the 'Clavella-branch' to be a delayed copepodid with the chalimus I stage inside. It is not known how many moults occur in the Naobranchiidae once the eggs are hatched and once the infective copepodid attaches to the gills.
Of particular interest is the filament used for attachment by the young, post-copepodid stage of Naobranchia variabilis observed here. The terminal plug inserted into the gill tissue and connected by a filament to the second maxillae resembles the frontal filament secreted by the frontal gland and used by copepodid and chalimus stages of lernaeopodids for attachment. The basal plug of the filament in these stages is grasped by claws of the second maxillae prior to the development of the bulla; the bulla is secreted by the frontal gland and held by fused tips of modified second maxillae (Piasecki 1989). Like the bulla of lernaeopodids, the filament of $N$, variabilis is held by the fused tips of the second maxillae, but the filament clearly does not have manubrial ducts and other features of a bulla (Kabata \& Cousens 1972). Post-copepodid stages of $N$. variabilis may retain the filament used by the copepodid for attachment, or the filament may be another structure such as a vestigial bulla that has become redundant during evolution, given the possible lernaeopodid-like ancestry of Naobranchiidae (Kabata 1981). In either case, this filament provides attachment whilst the second maxillae grow to encircle the gill filament. Detailed observations on the ontogeny of the attachment apparatus of the Naobranchiidae are needed.

Selection has favoured the loss of the versatile lernaeopodid bulla in favour of strap-like outgrowths of the naobranchid maxillae that restrict them to gill filaments (Kabata 1981). Concomitant with this restriction to the gills is a switch from the largely histophagous diet in lernaeopodids to a sanguinivorous diet in naobranchids.

The damage caused by individual Naobranchia variabilis is usually restricted to 1 gill filament and consists of compressed tissue and blood vessels beneath the maxillae with proliferated adjacent epithelial and connective tissue. This causes loss of surface area and interrupts blood flow, but there was no evidence of gill necrosis in Tetractenos hamiltoni due to restricted blood supply. Ergasilid copepods such as Ergasilus labracis and Ergasilus amplectens pinch off the gill filament blood supply, causing necrosis distal to the 
attachment site, but naobranchids cause only partial blockage of the blood supply (Kabata 1984). Perhaps the muscle bands within the naobranchid second maxillae permit some occasional lessening of the parasite's grip and allow blood flow to the distal end of the gill filament.

No more than $3.4 \%$ of total gill filament length and $8.6 \%$ of gill filaments were affected at the levels of infection by Naobranchia variabilis observed in this study. Individuals of the lernaeopodid Alella macrotrachelus affected up to $2 \%$ of gill filament length of Acanthopagrus australis, but the pathology was distributed over the tips of several gill filaments; in small fish the filaments were frequently swollen and fused (Roubal 1987b). Heavy infections by A macrotrachelus in aquaculture are lethal (Ueki \& Sugiyama 1979). Löpmann (1940) found that no more than $50 \%$ of gill surface area of Tinca vulgaris could be damaged by the copepod Ergasilus sieboldi; more severe infection caused death. Kabata \& Cousens (1977) reported 16 to $25 \%$ of gill surface of Oncorhynchus nerka damaged by 24 to 56 adults of the lernaeopodid copepod Salmincola californiensis, whereas 15 adult $S$. californiensis damaged up to $7.7 \%$ of gill surface area of larger Oncorhynchus mykiss. Compared to these data, it is unlikely that the damage caused by $N$. variabilis at the intensities observed in this study would be harmful to Tetractenos hamiltoni.

Large (adult) parasites caused more damage ( $\mathrm{PL}=$ compression and proliferation) than small (young) parasites. ML was an exact measure of compression damage, and was a better predictor than either TRW, TRL or TL of PL among age classes. Growth of NaObranchia variabilis was associated with an increase in size of the trunk, neck and second maxillae. Once the parasite matured and was fertilised, eggs were deposited in lateral egg pouches and TRW increased more than TRL (Roubal unpubl. data). TRW had a small positive effect on PL in addition to ML for the adult age class. This is explained by the large contribution of TRW to PR for adult parasites, whereas in other age classes, especially juveniles in which the trunk is little developed, ML explained most variation in $\mathrm{PL}$ and $\mathrm{PR}$.

The influence of adult TRW on PL and PR means that, for adults with the same ML, proliferation increases more for those adults with a wider trunk. A wider trunk signifies greater reproductive activity and an older age (Roubal unpubl. data). ML was best explained by TRL in early juveniles, wherein growth was associated with increasing trunk length, but in older classes TRW had more influence due to development and maturation of egg pouches. Although subadults cause less damage than adults, the slope of $\mathrm{PR}$ on $\mathrm{ML}$ is greater for subadults than adults, which implies that unit increases in adult ML had a lessened effect on proliferation; increases in TRW were more significant as shown above. Juveniles cause little tissue proliferation compared to compression and neither ML, TRW nor TRL explain variation.

It is not easy to explain why fish TL should have a negative effect on subadult ML once TRL and TRW have been fitted. A possible explanation is that larger fish have thicker gill filaments, and for parasites with the same trunk size, the maxillae that encircle the thicker gill filament are thinner. As fish increase in length, gill filaments increase in length, but fewer gill filaments are added (Farrell 1980, Hughes 1984). Thus, the number of filaments increased $39 \%$ for Tetractenos hamiltoni between 4.3 and $10.8 \mathrm{~cm}$ TL whilst the corresponding filament length increased $558 \%$. Thus, $\%$ gill filaments infected was similar to intensity of Naobranchia variabilis among fish becduse each infected filament usually had only 1 parasite attached, and there was not much difference in number of filaments among fish. However, relative to intensity of infection the \% total filament length damaged was less in larger fish and greater in smaller fish because larger fish have greater total filament length. Irrespective of fish size only a sinall amount of damage was done to the gills by $N$. variabilis.

Acknowledgements. I am grateful to David Graham and students in the Zoology Department, University of Queensland, for supplying the fish. A reviewer made useful comments on the manuscript.

\section{LITERATURE CITED}

Farrell AP (1980) Gill morphometrics, vessel dimensions, and vascular resistance in ling cod, Ophiodon elongatus. Can J Zool 58:807-818

Heegaard P (1947) Contribution to the phylogeny of the arthropods: Copepoda. Spolia Zoologica Musei Haun 8:1-236

Hughes GM (1984) General anatomy of the gills. In: Hoar WS, Randall DJ (eds) Fish physiology, Vol X. Gills. Part A. Anatomy, gas transfer and acid-base regulation. Academic Press, New York, p 1-73

Kabata Z (1968) Copepoda parasitic on Australian fishes VIII. Families Lernaeopodidae and Naobranchiidae. J Nat Hist 2:505-523

Kabata Z (1981) Copepoda (Crustacea) parasitic on fishes: problems and perspectives. Adv Parasitol 19:1-71

Kabata Z (1984) Diseases caused by metazoans: crustaceans In: Kinne O (ed) Diseases of marine animals, Vol IV, Part 1. Introduction, Pisces. Biologische Anstalt Helgoland, Hamburg, p 321-399

Kabata Z, Cousens B (1972) The structure of the attachment organ of Lernaeopodidae (Crustacea: Copepoda). J Fish Res Board Can 29:1015-1023

Kabata Z, Cousens B (1977) Host-parasite relationships between sockeye salmon, Oncorhynchus nerka, and Salmincola californiensis (Copepoda: Lernaeopodidae). J Fish Res Board Can 34:191-202 
Llewellyn $J$ (1954) Observations on the food and the gut pigment of the Polyopisthocotylea. Parasitology 44:428-437

Löpmann A (1940) Über die quantitative Bestimmung des Ergasilusbefalles an Schleien (Tinca vulgaris). Z Parasitenkd 11:474-483

Piasecki W (1989) Life cycle of Tracheliastes maculatus Kollar, 1835 (Copepoda, Siphonostomatoida, Lernaeopodidae). Wiadom Parazyt 35:187-245

Roubal FR (1987a) Gill surface area and its components in the yellowfin bream, Acanthopagrus australis (Günther) (Pisces: Sparidae). Aust J Zool 35:25-34

Roubal FR (1987b) Comparison of ectoparasite pathology on gills of yellowfin bream, Acanthopagrus australis (Günther) (Pisces: Sparidae): a surface area approach. Aust J Zool $35: 93-100$

Editorial responsibility: Wolfgang Körting,

Hannover, Germany
Roubal FR (1989) Pathological changes in the gill filaments of Acanthopagrus australis (family Sparidae) associated with the post-settlement growth of a lernaeopodid copepod, Alella macrotrachelus. J Fish Biol 34:333-342

Shotter RA (1971) The biology of Clavella uncinata (Muller) (Crustacea: Copepoda). Parasitology 63:419-430

Sutherland DR, Wittrock DD (1985) The effects of Salmincola californiensis (Copepoda: Lernaeopodidae) on the gills of farm-raised rainbow trout, Salmo gairdneri. Can J Zool 63:2893-2901

Ueki N, Sugiyama T (1979) Mass mortality of cultured juvenile black sea bream Mylio macrocephalus in cold-water season-1. Influence of the gill-parasitic copepod Clavellodes macrotrachelus. Bull Fish Res Stn, Okayama, Japan 1979:197-201

Submitted: September 24, 1998; Accepted: October 19, 1998 Proofs received from author(s): February 11, 1999 